\title{
Allopatric speciation in the desert: diversification of cichlids at their geographical and ecological range limit in Iran
}

\author{
Julia Schwarzer (D) Naghme Shabani $\cdot$ Hamid Reza Esmaeili • \\ Salome Mwaiko $\cdot$ Ole Seehausen
}

Received: 31 March 2016/Revised: 22 August 2016/Accepted: 27 August 2016/Published online: 15 September 2016

(C) Springer International Publishing Switzerland 2016

\begin{abstract}
Cichlids are textbook examples for rapid diversification and high species diversity. While in South America, several hundred and in Africa, more than 1500 species of cichlid fish have been described, only one single cichlid species, Iranocichla hormuzensis Coad 1982, was known from Iran, the easternmost range margin of the species-rich African cichlids (Cichlidae: Pseudocrenilabrinae). The aim of our paper was to assess the genetic and phenotypic diversity among populations of Iranocichla across most of its geographical range in Southern Iran. For
\end{abstract}

Guest editors: S. Koblmüller, R. C. Albertson, M. J. Genner, K. M. Sefc \& T. Takahashi / Advances in Cichlid Research II: Behavior, Ecology, and Evolutionary Biology

Electronic supplementary material The online version of this article (doi:10.1007/s10750-016-2976-3) contains supplementary material, which is available to authorized users.

J. Schwarzer · N. Shabani - S. Mwaiko ·

O. Seehausen $(\square)$

Department of Fish Ecology and Evolution, Center for

Ecology, Evolution \& Biogeochemistry, Eawag Swiss

Federal Institute of Aquatic Science and Technology,

6047 Kastanienbaum, Switzerland

e-mail: Ole.Seehausen@eawag.ch

J. Schwarzer

e-mail: schwarzer@evolbio.mpg.de

N. Shabani

e-mail: naghme.shabani@gmail.com

S. Mwaiko

e-mail: salome.mwaiko@eawag.ch this, we sequenced two mitochondrial genes and collected color observation of male nuptial coloration in different habitats. Besides conspicuous differences in male nuptial coloration, we found considerable genetic differentiation among Iranocichla populations pointing to the existence of at least two allopatric species, with no evidence of more than one species at one site. Diversification within Iranocichla started, based on our data, in the middle or late Pleistocene and was followed by further population differentiation and bottlenecks during isolation events in the last glacial maximum. Population dispersal leading to the population structure observed today most likely occurred in the course of the early Holocene sea-level rise.

Keywords Iranian cichlids · Cichlidae · Iranocichla $\cdot$ Vicariant speciation $\cdot$ Last glacial maximum

\author{
J. Schwarzer - N. Shabani - S. Mwaiko - O. Seehausen \\ Division of Aquatic Ecology, Institute of Ecology \& \\ Evolution, University of Bern, 3012 Bern, Switzerland \\ J. Schwarzer \\ Zoologisches Forschungsmuseum Koenig, Adenauerallee \\ 162, 53111 Bonn, Germany \\ N. Shabani \\ Laboratoire d'Ecologiee Alpine (LECA), UMR-CNRS \\ 5553, Université Joseph Fourier, Grenoble 1, \\ 38041 Grenoble Cedex 9, France
}




\section{Introduction}

Cichlids (Cichlidae) are, with more than 2000 species, the second largest perciformes fish family and one of the major vertebrate families (Kullander, 1998; Nelson, 2006). The geographical distribution of cichlids includes the freshwaters of Africa and Madagascar, the Jordan Valley, southern Iran, southern India and Sri Lanka, Central and South America, and Cuba and Hispaniola (Kullander, 1998). Their species richness and diversity in morphology, color, and behavior made them prime model organisms for the study of speciation and adaptive radiation and evolution of biological diversity more generally (Brawand et al., 2014). More than $73 \%$ of all cichlid species occur in Africa and Madagascar, 20\% in South America, and 5\% in Central America (Seehausen, 2015). Outside these continents, only three species are known from India and Sri Lanka (Jayaram, 1999), seven from the Jordan valley (four of which also occur in North Africa; Freyhof et al., 2014) and one from Iran (Esmaeili et al., 2010). This geographical disparity in diversity is striking. However, the diversity of cichlids outside the core distribution area of the family, i.e., at its range limits, is poorly investigated. The aim of our paper was to assess possible genetic and phenotypic diversity among and within populations of the Iranian cichlid genus, Iranocichla (Coad, 1982), across most of its geographical range in Iran. Iranocichla belongs to the African Haplotilapiine lineage (Schwarzer et al., 2009) but is at present geographically strongly isolated from all related cichlids in Africa and the Levant. It is considered a monotypic genus with the only species Iranocichla hormuzensis Coad, 1982, endemic to two provinces of Southern Iran (Fars and Hormuzgan) in waters draining into the Persian Gulf at the Strait of Hormuz. Iranocichla inhabits small streams and rivers characterized by extreme physical and chemical conditions: high and fluctuating temperatures and

H. R. Esmaeili

Ichthyology and Molecular Systematics Lab., Department of Biology, College of Sciences, Shiraz University, Shiraz 71454, Iran

e-mail: hresmaeili@shirazu.ac.ir

Present Address:

J. Schwarzer

Max Planck Institute for Evolutionary Biology, August-

Thienemann-Str. 2, 24306 Plön, Germany high mineral content (Booth, 1977; Coad, 1982; Abdoli, 2000), frequently subject to desiccation breaking up the continuous flow into isolated pools. The survival of cichlid populations in these pools varies between years and some pools may be fishless in one year and populated in another.

The nuptial coloration of male Iranocichla hormuzensis type specimens is blue-black (Coad, 1982), matching Iranocichla populations that we sampled at the type location in Mehran River in the south west of Iran (Coad, 1982, Fig. 1, Table 1). In other parts of the distribution range though, male coloration varies from black, greenish, brownish to bright orange and blue (Esmaeili \& Seehausen, pers. obs.). This diversity in phenotypes, the patchy geographical distribution, and the diverse and extreme physicochemical conditions in the habitats of Iranocichla motivated us to conduct an assessment of phenotypic and genetic diversity across the genus range and a first phylogeographic analysis of Iranocichla.

The goal of the present study was, therefore, to survey populations of Iranocichla for phenotypic and genetic variation, and to reconstruct phylogeographic relationships among them. We sequenced two mitochondrial genes, the control region (D-loop) and the protein coding NADH dehydrogenase subunit 2 (ND2), and collected color observations of male individuals from all sampled populations.

\section{Materials and methods}

Study system

Like many Haplotilapiines (Cichlidae: Pseudocrenilabrinae), Iranocichla is a female mouthbrooder and is strongly sexually dimorphic. Males, at least in some populations, construct elaborate bowers used to attract females (Esmaeili pers. obs.), an extended phenotype otherwise known from a number of African Oreochromis species as well as from several haplochromine species in Lake Malawi and from species of other cichlid tribes in the radiation of Lake Tanganyika (Fryer \& Iles, 1972). Bower building has been observed in Lar (Kol River), Mehran River (Esmaeili, pers. obs.), as well as in Shur River (Schulz, 2004) with some variation in the design of this extended phenotype among populations. Males exhibit bright nuptial coloration during the mating season, 


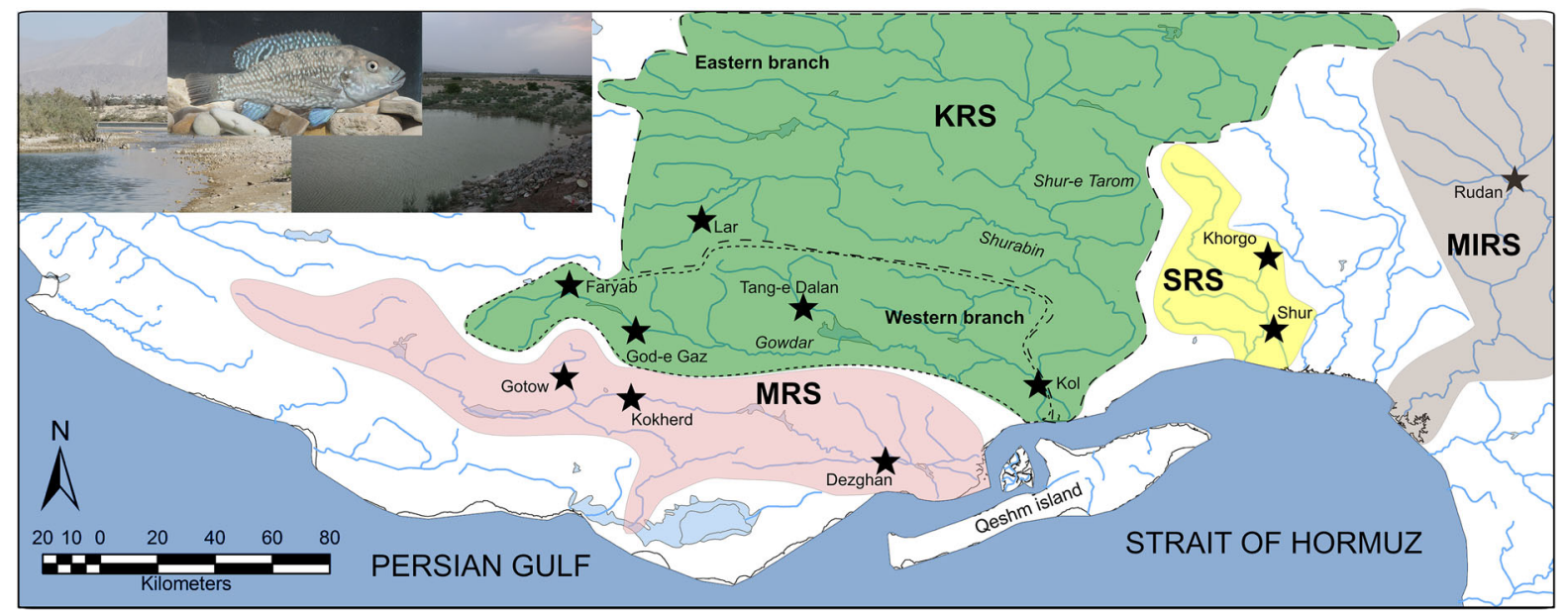

Fig. 1 Sampling sites of Iranocichla. Drainage systems are encircled and highlighted in different colors. Sampling locations marked by a star. In the upper left corner, habitat pictures of Iranocichla populations in Mehran (left) and Kol River System (right) are shown. The picture of the fish shows a male Iranocichla hormuzensis in nuptial coloration from Mehran River. MRS Mehran River System, KRS Kol River System, SRS Shur River System, and MIRS Minab River System

Table 1 Sampling locations and number of Iranocichla samples

\begin{tabular}{|c|c|c|c|c|c|}
\hline Location & Basin/subbasin & Latitude & Longitude & Altitude & $\mathrm{N}$ \\
\hline Mehran River, Kokherd village & Hormuz/Mehran & $27^{\circ} 04^{\prime} 50.1^{\prime \prime}$ & $54^{\circ} 28^{\prime} 24.4^{\prime \prime}$ & 258 & 9 \\
\hline Mehran River, Gotow village & Hormuz/Mehran & $27^{\circ} 08^{\prime} 38.8^{\prime \prime}$ & $54^{\circ} 15^{\prime} 46.9^{\prime \prime}$ & 352 & 11 \\
\hline Mehran River, Dejhghan & Hormuz/Mehran & $26^{\circ} 52^{\prime} 55.4^{\prime \prime}$ & $55^{\circ} 16^{\prime} 20.8^{\prime \prime}$ & 49 & 12 \\
\hline Faryab hotspring & Hormuz/Kol & $27^{\circ} 26^{\prime} 01.0^{\prime \prime}$ & $54^{\circ} 16^{\prime} 43.0^{\prime \prime}$ & 506 & 8 \\
\hline Tang-e Dalan & Hormuz/Kol & $27^{\circ} 23^{\prime} 14.6^{\prime \prime}$ & $55^{\circ} 00^{\prime} 14.0^{\prime \prime}$ & 364 & 1 \\
\hline Lar & Hormuz/Kol & $27^{\circ} 38^{\prime} 19.0^{\prime \prime}$ & $54^{\circ} 41^{\prime} 33.2^{\prime \prime}$ & 696 & 3 \\
\hline Kol & Hormuz/Kol & $27^{\circ} 07^{\prime} 19.5^{\prime \prime}$ & $55^{\circ} 44^{\prime} 55.4^{\prime \prime}$ & -23 & 1 \\
\hline God-e Gaz & Hormuz/Rasoul, Kol & $27^{\circ} 17^{\prime} 28.8^{\prime \prime}$ & $54^{\circ} 29^{\prime} 20.7^{\prime \prime}$ & 406 & 9 \\
\hline Shur River, Bandar Abbas-Minab Road & Hormuz/* & $27^{\circ} 17^{\prime} 43.4^{\prime \prime}$ & $56^{\circ} 29^{\prime} 15.4^{\prime \prime}$ & 16 & 3 \\
\hline Shur River, Khorgo hotspring & Hormuz/* & $27^{\circ} 31^{\prime} 21.3^{\prime \prime}$ & $56^{\circ} 28^{\prime} 12.7^{\prime \prime}$ & 140 & 11 \\
\hline Rudan River & Makran/Minab & $27^{\circ} 45^{\prime} 49.4^{\prime \prime}$ & $57^{\circ} 14^{\prime} 32.8^{\prime \prime}$ & 464 & 6 \\
\hline
\end{tabular}

Sites where Iranocichla was found during fieldwork in March-May 2013. The geographic range spans from South-West to SouthEast of Iran

* Drainage directly into the Persian Gulf

which typically begins in March and ends in June. Overall body color outside the spawning season in both sexes is a very light green or brown, golden or in some locations silvery, without obvious differences between the sexes (Esmaeili et al., 2008). In the spawning season, males develop a distinct nuptial coloration that varies considerably between populations (Fig. 2).

Distribution ranges of Iranian cichlids are restricted to the two South Iranian provinces Fars and Hormuzgan (Coad, 1982; Esmaeili, 2014). Streams and rivers that serve as habitats for Iranocichla hormuzensis all drain either into the Strait of Hormuz or into the Persian Gulf. The area around the Strait of Hormuz is rich in salt domes and most surface streams are saline, with salinity up to $80 \mathrm{mS}$. Stream waters range from clear to cloudy with water temperatures ranging from 15 to $33^{\circ} \mathrm{C}$ during winter and up to $40^{\circ} \mathrm{C}$ during summer (July, August), when water levels are low and air temperature reaches $45^{\circ} \mathrm{C}$ with no riparian vegetation to provide shade. Cichlids are found in pools and occasional backwaters and were caught at depths 

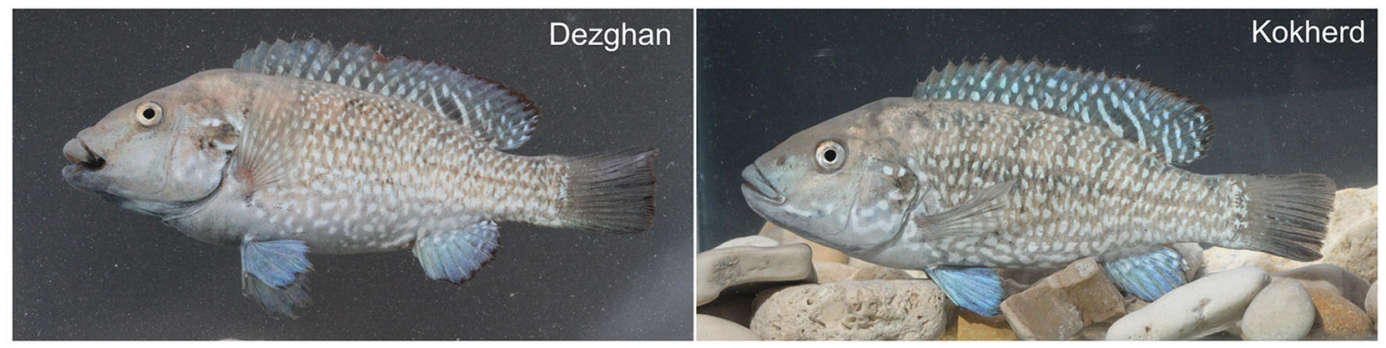

\section{Mehran River System}
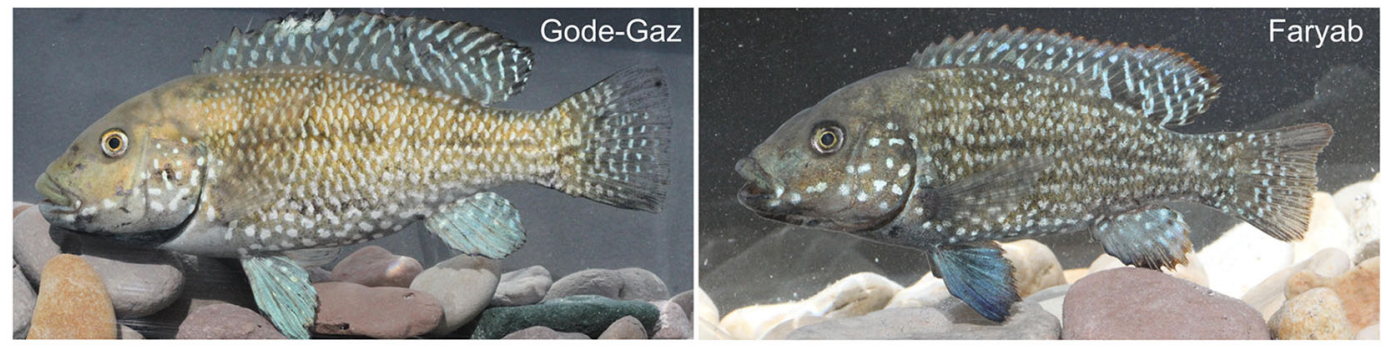

\section{Kol River System}
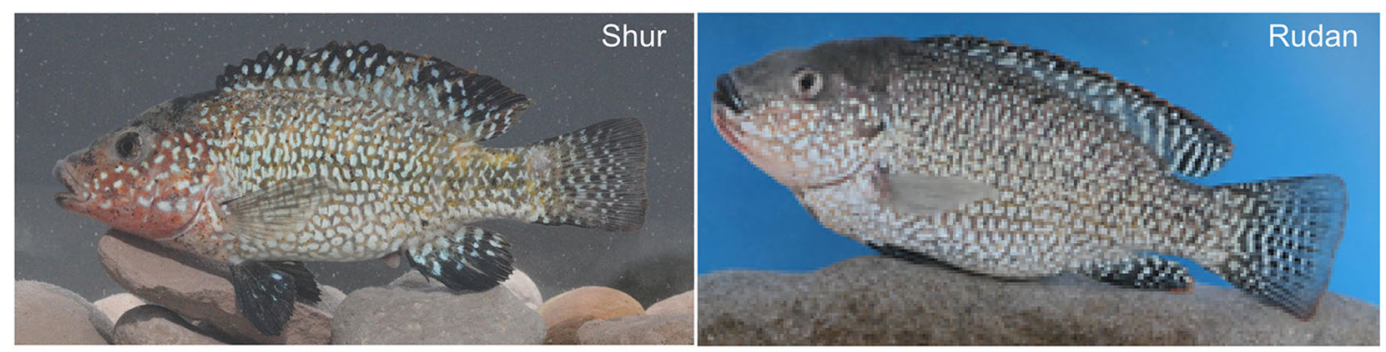

\section{Shur and Minab River Systems}

Fig. 2 Overview of male Iranocichla showing different nuptial coloration in different river systems

from $5 \mathrm{~cm}$ to $1 \mathrm{~m}$ over pebbles, sand, or mud. Aquatic vegetation is restricted to encrusting algae (Coad, 1982) that serve as main food source for Iranocichla (Hojat Ansari, 2008).

Our study area spans most of the distribution range of Iranocichla, with sampling sites distributed over four different rivers or river systems: (1) Mehran River System (MRS), (2) Kol River System (KRS), (3) Shur River System (SRS), and (4) Minab River System (MIRS), (Fig. 1). The Mehran River is $380 \mathrm{~km}$ long and drains through a broad delta with a surface area of $30 \mathrm{~km}^{3}$ to the Persian Gulf just west of Qeshm Island. During summer, the Mehran River is effectively dry, except for our sampling sites at Gotow, Kokherd, and Dezghan (Fig. 1), where water remains throughout the year (Esmaeili pers. obs.). The Kol River system from its main headwaters to the Persian Gulf is about $450 \mathrm{~km}$ long, $0.5-2.5 \mathrm{~m}$ deep, and drains into the Strait of Hormuz north of Qeshm Island with three major branches, Shur-e Tarom (Tarom Shur River), Shurabin River, and Gowdar River. The Shur River is the smallest of the river systems and drains into the Strait of Hormuz east of Qeshm Island. One collecting site, Khorgo, is one of several hot sulfurous springs in the Shur River system. The Rudan River is a tributary to the $160 \mathrm{~km}$ long Minab River, both part of the Minab River system, belonging to the Makran basin draining the South East of Iran into the Strait of Hormuz at its entrance into the Gulf of Oman (Fig. 1). The habitat is quite different from the other river systems in the study area, as it is the only permanent freshwater river in the Hormuzgan province (Afshar, 2000). 
Sample collection and color observations

Fish were collected during breeding season in March 2013 from eleven sites, spanning most of the geographical range of Iranocichla (Fig. 1, Table 1). A total of 81 individuals including 66 males and 15 females were caught using cast nets. Each individual was photographed in a portable aquarium immediately after capture using a Canon EOS 7D. Additionally, after anesthesia with Tricaine methane-sulfonate (MS222), photos of the fish were taken, and fin clips and a piece of pectoral muscles were excised from the right part of fish body and preserved in 100\% Ethanol. Whole specimens were preserved in $10 \%$ formalin. The number of fish obtained per sampling site varied between 1 and 12 (Table 1). Male nuptial coloration was described in detail from live photos whenever we obtained males in breeding coloration $(\mathrm{N}=43$ males from 9 populations, Table S1). Males included were all mature and mean sizes standard length (SL) of individuals from different river systems that were SL $8.5 \pm 0.8 \mathrm{~cm}$ in Mehran, $9.2 \pm 1.4 \mathrm{~cm}, 8.8 \pm 0.2$, and $8.2 \pm 0.8$ in Kol, Shur and Minab (Table S1).

DNA amplification and sequencing

Genomic DNA was extracted using Phenol:Chloroform:Isoamyl-alcohol (ratio of 25:24:1) after digestion at $55^{\circ} \mathrm{C}$ with lysis buffer and $20 \mathrm{mg} / \mathrm{ml}$ Proteinase $\mathrm{K}$ for $3 \mathrm{~h}$. PCR of each sample were conducted in a total reaction volume of $20 \mu \mathrm{l}$, containing $1.5 \mu \mathrm{l}$ of $10 \times$ reaction buffer (Promega), $0.6 \mu \mathrm{l}$ of $50 \mathrm{mM} \mathrm{MgCl} 2$ (Promega), $2 \mu \mathrm{l}$ of $2 \mathrm{mM}$ dNTPs (Promega), $0.5 \mu \mathrm{l}$ of $10 \mu \mathrm{M}$ of each primer of the ND2 gene (GLN_F and ASN_R, Kocher et al., 1995), or the D-loop gene (FISH_L15926F and Fish12s_R, Kocher et al., 1989) and finally $0.25 \mu \mathrm{l}$ of $5 \mathrm{U} / \mu \mathrm{l}$ Taq DNA polymerase (Promega) and $1 \mu \mathrm{l}$ of $30 \mathrm{ng} / \mu \mathrm{l}$ of genomic DNA. The PCR was run with an initial denaturation at $93^{\circ} \mathrm{C}$ for 3 min, followed by 5 cycles of denaturation at $93^{\circ} \mathrm{C}$ for $45 \mathrm{~s}$, annealing at $55^{\circ} \mathrm{C}$ for $45 \mathrm{~s}$, and primer extension at $72^{\circ} \mathrm{C}$ for $30 \mathrm{~s}$. The program was continued with 35 cycles of denaturation at $92^{\circ} \mathrm{C}$ for $30 \mathrm{~s}$, primer annealing at $55^{\circ} \mathrm{C}$ for $30 \mathrm{~s}$, and primer extension at $72^{\circ} \mathrm{C}$ for $1 \mathrm{~min} 30 \mathrm{~s}$. A final primer extension was then performed at $72^{\circ} \mathrm{C}$ for $2 \mathrm{~min}$. PCR products were diluted at a ratio of 1:15 with molecular grade water before preparing the sequencing reactions and purified using EXO-SAP (Affymetrix, OH) by incubating at $37^{\circ} \mathrm{C}$ for $15 \mathrm{~min}$., followed by enzyme inactivation at $80^{\circ} \mathrm{C}$ for $15 \mathrm{~min}$.

All sequencing reactions were conducted in both directions on an ABI $3110 \mathrm{xl}$ capillary sequencer (Applied Biosystems) at EAWAG in Kastanienbaum using the BigDye Terminator v3.1 Cycle Sequencing Kit using $1 \mu \mathrm{l}$ of the cleaned PCR product; $2 \mu \mathrm{l}$ of Betaine, $0.33 \mu \mathrm{l}$ of each $10 \mu \mathrm{M}$ concentration primer separately; and $2 \mu \mathrm{l}$ of BigDye Terminator v3.1 Cycle Sequencing kit and $1 \mu \mathrm{l}$ sequencing buffer (all reagents Applied Biosystems).

Phylogenetic tree reconstruction

Sequence data of 75 Iranocichla individuals were included in the final dataset. Six individuals had to be excluded, as they did not amplify for one or both genes. Sequences of several species expected to be closely related (Tristramella, Oreochromis, Sarotherodon, and Stomatepia, as a representative of Cameroonian crater lake endemics) as well as from some more distantly related groups (eight haplochromines from Lake Victoria, Lake George, and Lake Kivu and one Tylochromis) were downloaded from GenBank and used as a nested outgroup (Table S1). The East African desert cichlids of the genus Danakilia from the Danakil Depression at the Horn of Africa (Eritrea and Ethiopia) were suspected to be another lineage possibly closely related to Iranocichla (Trewavas, 1983). As for Danakilia no sequences were published yet, we sequenced both mitochondrial fragments from two individuals of Danakilia dinikolai (courtesy Giorgio Chiozzi, Natural History Museum Milano) and Melanie Stiassny, American Museum of Natural History) as well as from two individuals of the recently discovered Danakilia sp. "Sukoray" (courtesy Oliver Lukanus) and added these to the nested outgroup. All sequences were aligned using the MUSCLE algorithm (Edgar, 2004) implemented in Geneious 7.1.9 (http:// www.geneious.com, Kearse et al., 2012) resulting in 1047 bp ND2 and 997 bp D-loop for the phylogenetic analysis. The concatenated dataset for phylogenetic analyses consisted of 2044 bp and 103 sequences (75 Iranocichla, 28 outgroup individuals). The optimal data partition was estimated using PartitionFinder resulting in the following four partitions: ND2 with respect to codon positions and D-loop. Based on this, a maximum likelihood tree was generated using RAXML v.7.7.7 (Stamatakis, 2006) using the rapid 
hill climbing bootstrap algorithm with 1000 replicates and following ML search under the GTRGAMMA model. Branches not supported by 50\% bootstrap values were collapsed. Two separate gene trees based on either ND2 or D-loop alone were additionally reconstructed using the same settings as described above. The Levant endemic Tristramella could only be included in the ND2 analysis because no D-loop sequences (and no tissue samples) were available for this taxon.

Population structure and demographic history

Molecular diversity indices were calculated for each river system, including the number of unique haplotypes (Nhap), the number of polymorphic sites (S), haplotype diversity (He), and nucleotide diversity (p) using ARLEQUIN v3.5.2.2 (Excoffier \& Lischer, 2010). A statistical parsimony network was constructed using TCS 1.21 (Clement et al., 2000) under default settings. For proper visualization, the resulting network was redrawn by hand. The dataset used here consisted of an alignment of 2044 bp (1047 bp ND2 and 997 bp D-loop) and 75 Iranocichla sequences (74 Iranocichla sequences from our own sampling locations and one individual from the Kol River system collected by Hannes Svardal in 2006). A spatial analysis of molecular variance (samova) was conducted to define the number of groups among Iranocichla populations that are geographically homogeneous but genetically maximally differentiated from each other. This was done based on the simulated annealing procedure implemented in the program SAMOVA 1.0 (Dupanloup et al., 2002). Hereby the among-group component $\left(F_{\mathrm{CT}}\right)$ of the overall genetic variance is maximized to identify the optimal grouping option (K). The assumed number of groups (K) was set to vary between 1 and 4, with 10,000 iterations and repeating each run 5 times for each value of $\mathrm{K}$. A fixation index based on haplotype frequencies $\left(F_{\mathrm{ST}}\right)$ was then calculated for pairwise comparisons between river systems and maximally genetically differentiated groups.

Departures from mutation-drift equilibrium were assessed by calculating Tajima's D (Tajima, 1989) and Fu's FS (Fu, 1997) using Arlequin 3.5.2.2 (Excoffier $\&$ Lischer, 2010). Both neutrality tests can provide information on possible population expansions or indicate recent bottlenecks. Tajimás D test is based on the allele frequency distribution of segregating nucleotide sites, whereas Fús FS test is based on the frequency distribution of haplotypes. In populations with constant population size in the past, values for Tajimás D and Fús Fs indices are nearly zero. Positive values indicate a bias toward intermediate frequency alleles, whereas negative values indicate a bias toward rare alleles. The latter can be an indicator for recent population expansion, whereas significant positive values indicate a population subdivision or recent population bottlenecks. Significance for the two neutrality tests was assessed by running 1000 coalescent simulations in accordance with the assumptions of selective neutrality and population equilibrium using a coalescent approach (Excoffier \& Lischer, 2010). To characterize the type of demographic history and the age of a potential expansion, mismatch distributions of pairwise differences between the sequences were calculated using Arlequin 3.5.2.2 (Excoffier \& Lischer, 2010). For each river system and each distinct clade identified in the phylogenetic analysis or haplotype network reconstruction, the shape of the mismatch distribution was compared to a distribution from sequence data simulated under alternative expansion models. The fit between observed and predicted mismatch distributions was subjected to two different goodness of fit tests (standardized squared differences (SSD) and raggedness index tests; Harpending, 1994), providing information on how well the data simulated under different models of population expansion fitted the observed mismatch distributions. The moment estimators of time to expansion Tau $(\tau)$ and the mutational parameters before (Theta $(\theta)_{0}=2 \mu \mathrm{N}_{0}$ ) and after expansion (Theta $\left.(\theta)_{1}=2 \mu \mathrm{N}_{1}\right)$ were determined following the method of Schneider and Excoffier (1999). Units are expressed in mutational time, where $N_{0}$ and $N_{1}$ are respective female effective population sizes before and after an expansion that occurred $\tau$ generations ago.

As any divergence within Iranocichla occurred most likely within the past 1-2 million years, rates of the molecular clock are not expected to be linear and standard mt-DNA mutation rates could not be applied (Ho et al., 2005). Therefore, divergence times of the split within Iranocichla and within the two respective clades were calculated using the power functions of Genner et al. (2007, Fig. 5c, d in their paper) that are also based on the D-loop region, showing that divergence in this region of the mitochondrial genome 
is rapid for one million years and then declines until reaching a stable baseline substitution rate at around two million years. The underlying relaxed molecular clocks were calibrated either using the cichlid fossil record or the fragmentation of Gondwanaland (Genner et al., 2007). Genetic distances (uncorrected p-distances) within Iranocichla were calculated based on an alignment of D-loop including all Iranocichla individuals (997 bp, $N=75$ ) in MEGA 6 (Kumar et al., 2004). Additionally one internal calibration point of 100,000 yrs was set at the onset of the recent Lake Victoria superflock (LVRS) haplotype radiation in haplochromine cichlids (Verheyen et al., 2003), represented in our case by $H$. sauvagei of Lake Victoria and several Lake Kivu species. Uncorrected p-distances were here calculated based on a shorter alignment of D-loop (792 bp, $N=97$ ), as most haplochromine sequences from GenBank were shorter.

\section{Results}

Phenotypic variation between drainage systems

Male breeding coloration varied remarkably among the sampling sites but not within, and these differences coincided with major drainage system divides. Variation in breeding coloration of the Iranocichla males sampled in our study can mostly be summarized as follows: (1) blue-black or yellowish-brown body, (2) "Tilapia mark" in the dorsal fin present or absent, (3) pale blue, black, or orange to red head and chest, and (4) blue or black pelvic and anal fins. Males from Mehran River had a yellowish-brown body coloration with a hint of light blue, peppered with iridescent light-blue spots all across the body, the spots being smaller or equal in size to the background between them, a pale bluish head and chest with large iridescent blue spots on operculum and preoperculum, and a clearly visible and well-defined "Tilapia mark" in the dorsal fin (Fig. 2). The pelvic fins and the anal fin are bright light blue with some iridescent blue spots; the dorsal fin is peppered with small blue iridescent spots arranged in about 3 rows and has a vine red edge, and the caudal fin is dark without spots. Male individuals from all other River systems had no well-defined "Tilapia mark," except for the ones from sampling location Faryab hotspring, in the neighboring Kol
River system, where males resemble the nuptial coloration of those from Mehran River, albeit being darker with iridescent blue spots on the caudal fin and on the dorsal fin being connected to stripes (Fig. 2). The two males from Faryab hotspring in breeding dress, however, were smaller than those sampled from other sites in the Kol River system (mean SL $7.05 \pm 0.21$ compared to $9 \pm 1.31$ ), and more male individuals from Faryab are needed to rule out an effect of immaturity on the presence of the "Tilpia mark." The body coloration of males from elsewhere in the Kol River system was yellowish-brown with a black chest and no visible "Tilapia mark." All of them had iridescent blue spots on all fins including the caudal fin and a vine red edge to the dorsal fin. The breeding dress of males from Shur River system and Minab River system (Rudan River) was completely different from all populations of Mehran and Kol river systems, with a bluish-black body; dark, peppered with iridescent light-blue spots all across the body, the spots being larger than the background area between them, giving the fish a reticulated appearance, a bright orange to red chest and in most males also a bright red head, and no well-defined Tilapia mark. Contrary too to the other populations, males have darker pelvic and anal fins with large iridescent blue spots, and the edge of the dorsal fin is more orange than red (Fig. 2). From one population (Tang-e Dalan), no males in breeding dress were available.

Mitochondrial phylogeny

The monophyly of the genus Iranocichla was well supported (BS = 100), whereas sistergroup relationships with the remaining Oreochromines or Danakilia were not well resolved based on the concatenated dataset (all $\mathrm{BS}<50$, Fig. 3) or in the single gene trees (all BS $<50$, Fig. 3, Figure S1). Within Iranocichla individuals from Kol River system, Shur River system and Minab River system formed a well-supported monophyletic clade (clade B, BS = 96), distinct from all individuals from Mehran River system (clade A, Fig. 3, BS = 52). Trees based on ND2 and D-loop yielded the same topology as the concatenated dataset, though with slightly different support values (Figure S1). Based on D-loop, monophyly of clade B was supported with a BS of 80 and based on ND2 with $\mathrm{BS}=96$. Clade A was weakly supported (D-loop, $\mathrm{BS}=28$ ) or appeared polyphyletic (ND2). 


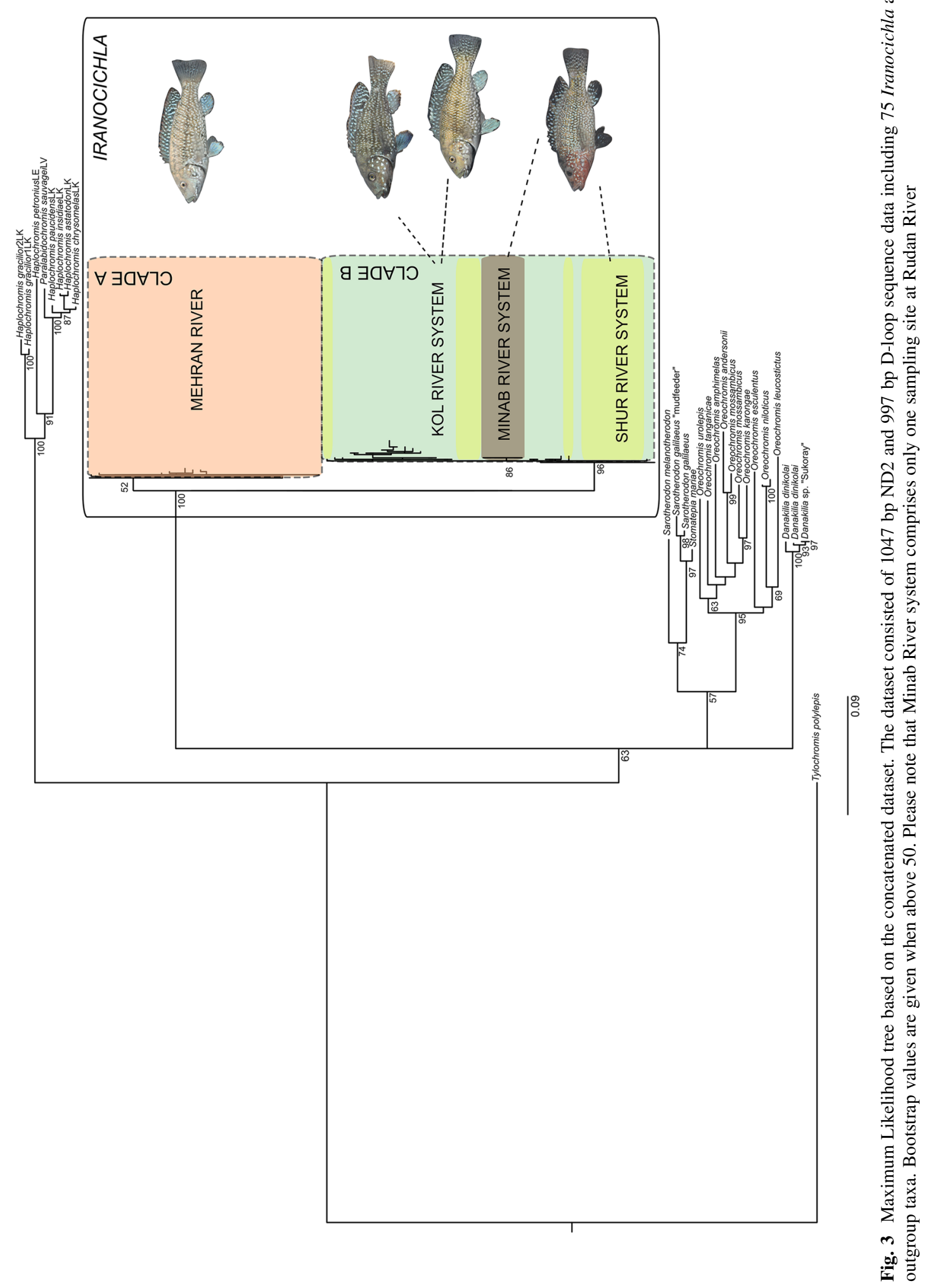


Population structure and demographic history

Summary statistics for each river system and for the two divergent haplotype clades A and B are shown in Table 2. A total of 46 different haplotypes were present in our Iranocichla samples. The two large haplotype clades A and B were separated by 17 mutations (Fig. 4). Clade A is restricted to the Mehran River system, with many individuals from all three Mehran populations sharing the same most common haplotype (A-1, Fig. 4). Haplotype variation within this clade is rather high with 20 different haplotypes spanning distances of up to nine mutations. Haplotypes from all other drainage basins fell into clade B. Within this clade, there were two common haplotypes (B-1, B-2, Fig. 4). The central haplotype B-1 dominates in the population from Khorgo in the Shur River system. The two sites in the Shur River, Khorgo, and Banda Abbas have five additional haplotypes, each between one and three mutations separate from haplotype B-1. Individuals from Rudan (Minab River system) to the East of the Shur River, all share a single haplotype (B-2), two mutations apart from the central haplotype in clade $\mathrm{B}$ and not shared with other populations. Interestingly, none of the populations from the western arm of the Kol river system (Kol, God-e Gaz, Faryab, Tang-e Dalan) shared any haplotypes with the Shur and Minab River system populations, but the population from the eastern arm of the Kol (Lar) did (Fig. 4). Kol River populations were genetically more diverse than those of other systems (Table 2), with no haplotype shared with any other drainage system (Fig. 4). The highest $\mathrm{F}_{\mathrm{CT}}$ value in the samova was observed under the $\mathrm{K}=3$ model $\left(F_{\mathrm{CT}}=0.835, P<0.05\right)$, separating all populations from Mehran River system from Minab River system and from a group comprising populations from Shur and Kol River systems. Only slightly worse was $\mathrm{K}=4\left(F_{\mathrm{CT}}=0.833, P<0.05\right)$ additionally placing populations from Kol and Shur river systems in separated groups.

Neutrality statistics and mismatch distributions were calculated for the two large phylogenetic clades within Iranocichla: clade A (Mehran River system, $N=32$ ) and clade B (Kol, Shur and Minab river systems, $N=42$ ) and for rivers within clade B separately (Kol, $N=22$ and Shur, $N=14$ ). Individuals from the Rudan sampling site in the Minab River system had to be excluded, as only one haplotype was present. The results of Tajimás D and Fús FS tests, including associated p-values are presented in Table 2. Tajimaśs D suggested significant deviation from neutrality in clade A, and Fús FS values were negative and significant for clade A and B as well as for Shur and Kol river systems tested separately (Table 2), indicating an excess of rare nucleotide sites and/or haplotypes compared to the expectation under an equilibrium model of evolution.

The goodness of fit tests could neither reject the model of a (sudden) demographic population expansion nor of a recent spatial expansion (all $P>0.05$, Table 3, Figure S2) based on the fitting of the empirical data of mismatch distributions for all three tested river systems (Mehran, Kol and Shur) to the underlying models. Mismatch distributions in all three groups were fitted best by a unimodal model

Table 2 Summary statistics for each river system and for the two divergent haplotype clades A and B

\begin{tabular}{|c|c|c|c|c|c|c|c|}
\hline Clade/river system & $\mathrm{N}$ & Nhap & $\mathrm{S}$ & $\mathrm{He}$ & $\pi$ & Tajimás D & Fús Fs \\
\hline Kol & 22 & 18 & 28 & $0.9767(0.01)$ & $0.0024(0.001)$ & $-0.699 n s$ & $-8.3903 * *$ \\
\hline Shur & 14 & 7 & 7 & $0.9512(0.01)$ & $0.0005(0.000)$ & $-0.944 \mathrm{~ns}$ & $-12.090 * *$ \\
\hline Minab & 6 & 0 & 0 & $0.8824(0.03)$ & 0 & - & \\
\hline Mehran (clade A) & 32 & 28 & 30 & $1.00(0.01)$ & $0.0016(0.001)$ & $-1.968 *$ & $-26.102 * *$ \\
\hline $\begin{array}{l}\text { Kol, Shur, } \\
\text { Minab (clade B) }\end{array}$ & 42 & 35 & 37 & $0.9889(0.01)$ & $0.0020(0.001)$ & $-1.339 \mathrm{~ns}$ & $-25.861 * *$ \\
\hline
\end{tabular}

$N$ number of sequences analyzed, Nhap number of haplotypes, $S$ nb of polymorphic sites, He haplotype diversity (SD), $\pi$ nucleotide diversity (SD), $n s$ not significant

* Significant $P$-values $<0.05$

** Significant $P$-values $(<0.001)$ 


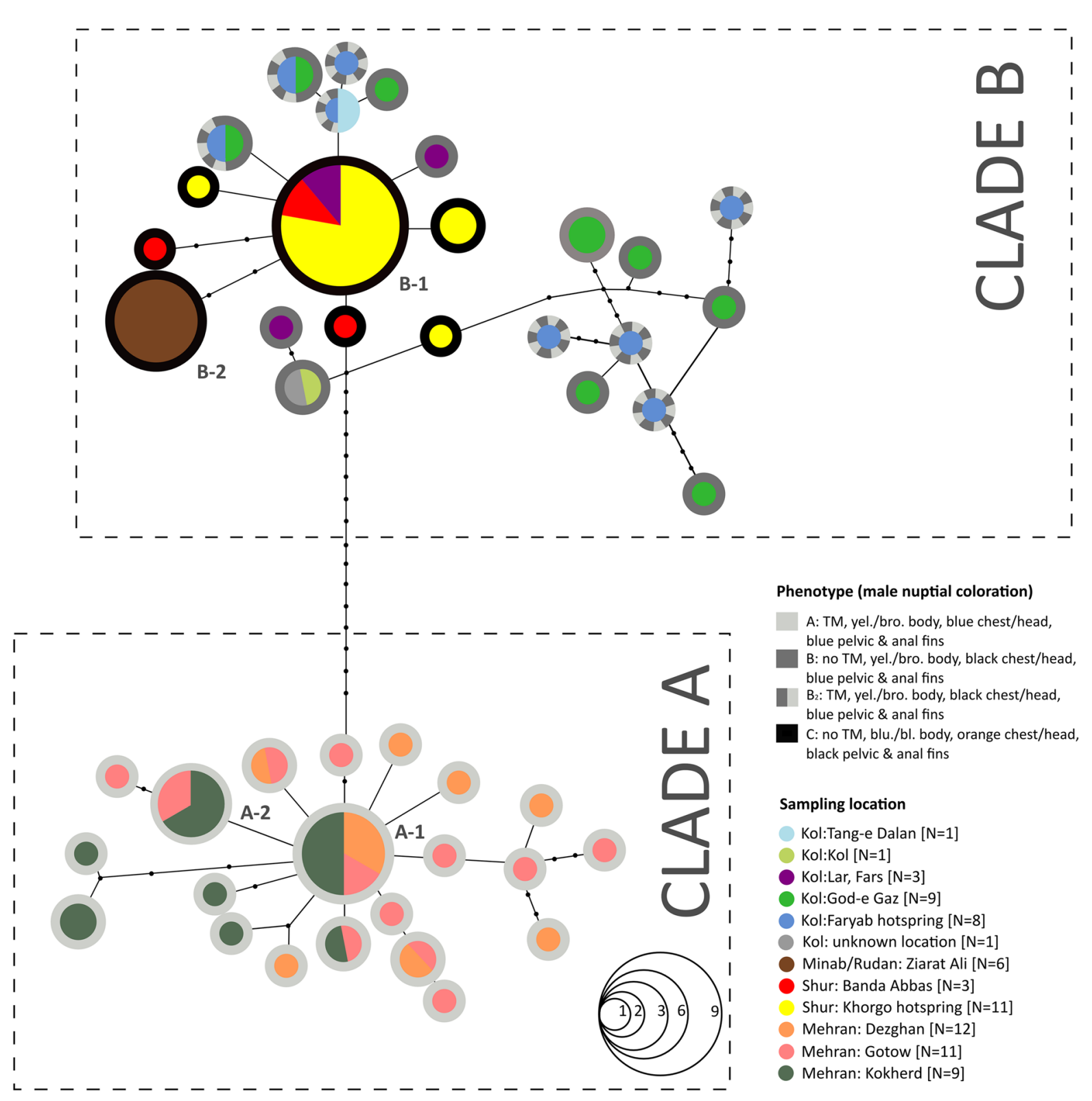

Fig. 4 Haplotype network showing the mutational relationships among the analyzed mitochondrial ND2 and D-loop haplotypes of Iranocichla specimens from most of their distribution range in Iran. Each line in the network represents a single mutational change, small black dots indicate missing haplotypes. The color of the inner full circles corresponds to the

(supporting the results of the neutrality statistics, indicating recent population expansions in all populations, Table 3), even though the mismatch distribution in the Kol River system showed two additional peaks with higher number of mismatches, indicating some population substructure in the past (Figure S2). presented color code for the sampled region and the color of the outer ring to suggested male color phenotype. The size of the circles corresponds to the number of individuals sharing the haplotype. TM "Tilapia mark," yel./bro. yellowish/brown, blu./ bl. bluish/black

Divergence time estimates for the onset of diversification in Iranocichla were 160,484/219,317/ 318,181 years ago, based, respectively, on fossil priors, Gondwana priors (Genner et al., 2007) or internal calibration (100,000 years ago at the base of the LVRS) used to calibrate the molecular clock. The 
Table 3 Mismatch analysis inferred for the combined ND2 and D-loop dataset

\begin{tabular}{lllll}
\hline Mismatch analysis & Clade A (Mehran) & Clade B (Kol, Shur, Minab) & Kol river system & Shur river system \\
\hline Tau $_{\text {spa. exp. }}$ & $2.02(0.52-4.34)$ & $2.25(0.31-5.80)$ & $3.44(1.66-6.23)$ & $0.96(0.24-1.38)$ \\
$\theta_{\text {spa. exp. }}$ & $1.55(0-3.41)$ & $2.44(0-5.73)$ & $1.97(0-5.38)$ & $0.01(0-0.54)$ \\
Migration $_{\text {spa. exp. }}$ & $999(11.086-\mathrm{inf})$ & $15.77(0.73-\mathrm{inf})$ & $28.89(6.94-11.89)$ & $999(2.18)$ \\
$\mathrm{SSD}$ & $0.003 \mathrm{~ns}$ & $0.004 \mathrm{~ns}$ & $0.007 \mathrm{~ns}$ & $0.012 \mathrm{~ns}$ \\
Raggedness index & $0.023 \mathrm{~ns}$ & $0.015 \mathrm{~ns}$ & $0.022 \mathrm{~ns}$ & $0.113 \mathrm{~ns}$ \\
Tau $_{\text {dem. exp }}$ & $2(0.33-5.24)$ & $3.2(0.09-10.14)$ & $4.58(1.17-7.76)$ & $0.97(0.47-1.52)$ \\
$\theta_{\text {Odem. exp. }}$ & $1.55(0-4.74)$ & $1.74(0-3.74)$ & $0.99(0-1.14)$ & $0(0-0.03)$ \\
$\theta_{1 \text { dem. exp. }}$ & $999(7.66-\mathrm{inf})$ & $12.27(7.79-\mathrm{inf})$ & $20.86(6.2-\mathrm{inf})$ & $999(1.39-\mathrm{inf})$ \\
$\mathrm{SSD}$ & $0.003 \mathrm{~ns}$ & $0.003 \mathrm{~ns}$ & $0.006 \mathrm{~ns}$ & $0.0125 \mathrm{~ns}$ \\
Raggedness index & $0.024 \mathrm{~ns}$ & $0.015 \mathrm{~ns}$ & $0.022 \mathrm{~ns}$ & $0.113 \mathrm{~ns}$ \\
\hline
\end{tabular}

$\operatorname{Tau}(\tau)$ moment estimator of time to expansion, mutational parameter Theta $(\theta)$ before $\left(\theta_{0}\right)$ and after expansion $\left(\theta_{1}\right), \operatorname{Spa}$. $\exp$ spatial expansion, dem.exp demographic expansion, $S D D$ standardized squared differences, $n s$ not significant. $95 \%$ confidence interval in brackets

onset of diversification within clade A was estimated at $8,647 / 8,831 / 48,636$ years and that within clade B at $17,276 / 18,274 / 81,818$ years ago.

Genetic differentiation based on haplotype frequencies was significant among the major geographical groups (River systems) within clade B (Table S2). Genetic differentiation between the three sampling sites in the Mehran River system was much lower but still significant (Table S3).

\section{Discussion}

Cichlids are textbook examples in evolutionary biology for forming extensively diverse adaptive radiations (Seehausen, 2006) as well as nonadaptive radiations (e.g., Trewavas, 1983), sometimes in very short periods of time. Iranocichla hormuzensis was considered a monotypic taxon, distributed over a relatively large geographic area and several isolated river systems. Several of its relatives in the genera Oreochromis, Sarotherodon, Danakilia, and Tristramella are relatively diverse in African rivers, typically with sister species being separated by drainage divides between adjacent river systems, and have radiated into small species flocks in lakes in Africa and the Jordan Valley (Wagner et al., 2012). Our phenotypic and mitochondrial sequence data suggest that Iranocichla is more diverse than previously thought and includes between two and four morphologically and genetically distinguishable and allopatrically distributed entities.

Phylogenetic inference based on two mitochondrial genes, haplotype network reconstruction, Samova and haplotype frequency-based $\mathrm{F}_{\mathrm{ST}}$ values all corroborate that Iranocichla sampled from 11 sites in Southern Iran are distributed into at least two well divergent phylogeographical clades (henceforth called "clade A" and "clade B"). A further substructure within clade B is revealed mainly based on the haplotype network and the results of a spatial analysis of molecular variance (samova). The samova, when assuming a group structure of $K=3$ assigns individuals from Minab and from Shur and Kol river systems to separate groups. Based on the haplotype network, a more complex structure is indicated, with individuals from Shur and Minab river systems sharing no haplotypes with each other and with individuals from the western branch of the Kol River system (Fig. 4). One individual from Lar, the northernmost and only sampling location in the eastern branch of the Kol River system (Fig. 1), shares one haplotype with individuals from Shur River system, whereas two other haplotypes are one and five mutations away from this common Shur haplotype (Fig. 4). Within clade B, genetic diversity (haplotype and nucleotide diversity) is highest in the Kol River system (Table 2) indicating a population with relatively stable demographic history or a population that experienced some admixture event in the past (also hinted at by the two peaks in the 
mismatch analysis). Populations in the Shur River system have a lower genetic diversity and individuals from the sampling site in the Rudan River (Minab River system) all carry the same mt-haplotype (Table 2). This points either toward a recent colonization of the Shur river system and Rudan River, e.g., from Kol River system, or, as haplotypes present in Shur River system appear ancestral to most of the Kol haplotypes (Fig. 4), major bottlenecks followed by a recent population expansion in Shur populations (Figure S2) and subsequent colonization of the Rudan River in the Minab River system and possible gene flow into the Kol River system from Shur. The two major mitochondrial clades $\mathrm{A}$ and $\mathrm{B}$, and also the divergent haplotype groups within clade B coincide not only with different river basins but also with conspicuous differences in male breeding coloration. Male breeding coloration plays important roles in female mate choice and male-male competition in haplotilapiine cichlids (Kocher, 2004; Seehausen \& Schluter, 2004; Dijkstra et al., 2010). Distinct differences in male breeding color, such as red versus blue, are often associated with behavioral reproductive isolation (Selz et al., 2014a, b), suggesting that Iranocichla is (or has been) undergoing allopatric speciation (Fig. 2, see also Esmaeili et al., 2015).

Differences in male nuptial coloration and the remarkably high genetic differentiation between Iranocichla populations west and north/east of Qeshm Island in Southern Iran (clade A and clade B) point toward allopatric speciation that, based on the results from the molecular clock approaches, began between $\sim 160$ and 318 kya (depending on the molecular clock calibration used). The distinctive color differences between fish from the Kol River system on the one hand and those from Shur and Minab river systems on the other, and the nearly complete lack of haplotype sharing between the river systems, indicate the additional existence of two younger allopatric incipient species within clade B: a red headed species in Shur and Minab and a dark blue/black species in Kol. The divergence of these forms seems to be relatively recent and Kol populations appear to be structured based on their mitochondrial genes, with the most distantly related haplotypes occurring the same locality, possibly suggesting an old stable population or a case of more recent admixture with gene flow from the Shur River system into Kol River system. To investigate the demographic and gene flow history in more detail in future studies, next generation sequencing will be needed, ideally combined with a denser population sampling spanning the complete range of Iranocichla across Kol, Shur, Hasan Langi and Minab River systems. Additionally, behavioral mate choice experiments in aquaria will be needed to test for behavioral reproductive isolation.

Paleogeography of South Iran and the Persian Gulf suggests a scenario of Pleistocene vicariance

The present distribution of Iranocichla is regarded as a relict of a once much wider distribution of Haplotilapiine cichlid fish across the Arabian Peninsular and/ or the Tigris-Euphrates basin (Coad, 1982). Their closest living relatives have been suggested to be either Tristramella (Schwarzer et al., 2009), a genus endemic to the Levant, the widely distributed Sarotherodon, or Danakilia endemic to lakes in the Danakil Depression of northern Ethiopia and Eritrea (Trewavas, 1983; Stiassny et al., 2010). The latter relationship has been proposed solely based on morphological data (Trewavas, 1983). Our sequence data could not support either of these genera as closer than the others to Iranocichla (Fig. 3). This, however, needs to be evaluated with more data, e.g., from next generation sequencing.

Banister and Clarke (1977) considered that dispersal of aquatic organisms across the Arabian Peninsula and hence exchange between Africa and Iran could have been possible through freshwater corridors during the Pliocene or Pleistocene. Kosswig $(1965,1973)$ suggested that headwaters of the Levant rivers and the river systems of Mesopotamia were close together at various times during the late Pliocene (3.6 to $\sim 2.58 \mathrm{Ma}$ ). This could have enabled a dispersal of ancestors of Iranocichla from Ethiopia via the Levant to Iran. Alternatively, dispersal may have happened during the Miocene or early Pliocene via the Arabian Peninsula to Southern Iran. Published age estimates for the MRCA of Tristramella and Iranocichla based on four mitochondrial and five nuclear genes ranged from 5.6 to 12.8 mya (Schwarzer et al., 2009). These divergence estimates are not inconsistent with the Miocene hypothesis but would seem too old for a Pliocene event.

Southern Iran stretches over three tectonic plates, and its paleogeography is shaped by an intensive tectonic activity. Movement of these plates began in 
the early Pleistocene ( $\sim 1.8$ mya) and caused significant landscape changes (Regard et al., 2004, Teimori, 2013). Iranocichla nowadays inhabit river systems west and north/east of Qeshm Island, and these populations, clades $\mathrm{A}$ and $\mathrm{B}$, carry very different mitochondrial haplotypes, indicating a long period of separation. Divergence of these clades began, based on our data most likely in the late or middle Pleistocene (between $\sim 160$ and 318 kya, depending on the molecular clock used). It is likely that populations became isolated by that time through geographical and geological isolation of drainage systems caused by climate change in the lower to middle Pleistocene (Kehl, 2009), e.g., associated with increasingly dryer climates. Based on our data (haplotype network and demographic history reconstruction, low genetic diversity, and little haplotype sharing), we propose the following scenario for the diversification within Iranocichla: (1) Iranocichla populations persisted throughout the Pleistocene in the Mehran and Kol River systems, but remained isolated between these basins ever since their first split $\sim 160$ and 318 kya. (2) Shur and Minab river systems (including Rudan River) were only colonized during or after the Last Glacial Maximum (LGM) from the Kol river system (onset of diversification within clade B: 17-81 kya), most likely through occasional long distance dispersal through the Sea of Hormuz. Because the Shur River system and Rudan River (Minab River system) now are dominated by haplotypes that appear ancestral to those of both Kol clades, this scenario would require that most of these haplotypes subsequently became rare or lost in the Kol River system, for example, through bottlenecks caused by dry conditions during the LGM (Sarntheim, 1972, Purser \& Seibold, 1973). During that period (starting $\sim 24.5$ kya), most of the Persian Gulf seafloor became exposed, and Qeshm island was likely connected to land (Lambeck, 1988, 1996). While this would have increased the geographical distance between the clade A north of the island and clade B south of it, it might have permitted genetic exchange between Iranocichla populations within the southern clade (e.g., via ancient river connections that are now under the sea) until a renewed flooding of the area began $\sim 18$ kya (Lambeck, 1996; Teller et al., 2000). Alternatively, Iranocichla of clade B may have entered the Shur River system earlier and persisted both in Shur and Kol river systems during droughts in the LGM. They may then have colonized Rudan River in the Minab River system from Shur and also recolonized the Kol River system from Shur during or just after the LGM. This would explain the central position within clade B of Shur haplotypes in the haplotype network and the existence of and admixture between two haplotype clades in the western arm of the Kol River system. Yet another possibility is that Shur and Kol river systems were colonized at the same time (the reconstructed most recent common ancestor haplotype of all Kol, Shur, and Rudan haplotypes is extinct or absent in our data) and started to diverge into a western Kol and an eastern Kol/Shur clade, and that the western Kol afterward was colonized a second time from the east through river capture of the eastern Kol which may once have drained toward the Shur. Subsequently more recent bottlenecking of eastern Kol and Shur populations would have led to their divergence in haplotype frequencies without much sequence divergence.

\section{Conclusion}

This study has provided first evidence for considerable genetic divergence and phenotypic differentiation between geographical populations of Iranocichla. The mitochondrial genealogy, haplotype network, and $F_{\mathrm{ST}}$ values all reveal strong genetic differentiation between major drainage systems, some ancient, others much more recent. At the same time, genetic differentiation between populations within major drainage systems is restricted to the populations of the western and the eastern branches of the Kol River system. Clades defined based on mitochondrial DNA (A vs. B) and differentiated populations within clade B (western Kol, eastern Kol, Shur, and Rudan River) also have distinct male breeding coloration, whereas breeding coloration from sampling sites belonging to the same genetic populations is identical, and only one breeding coloration type was observed in any one site. We suggest that the genetically differentiated populations with different nuptial coloration represent distinct biological species, something that will need behavioral testing in the future. Differentiation in this system would seem best explained by allopatry involving vicariance and possibly founder events interacting with divergent sexual selection, but adaptation to different habitats is a possibility. Whether 
these differentiated forms have evolved behavioral mating isolation, and the possible role of divergent sexual selection should be investigated in the future, as should the population genomics of differentiation and admixture, as well as demography using next generation sequencing data. Given the fragile habitats and small population sizes, the different Iranocichla taxa that we identified should be considered separate conservation and management units. Finally, the rivers that we could not sample (tributaries of the Hasan Langi) should be sampled to complete the picture we started to develop here.

Acknowledgments We are pleased to thank M. Masoudi, H. Mehraban, and A. Gholamifard for their help during field work and with photography. We also thank Vafadar and H. Hashemi from Hormuzgan Environment Department for supporting us with field trip facilities. We further thank Hannes Svardal, Ralph Peters, Stephan Koblmüller, and two anonymous reviewers for comments on earlier versions of the manuscript. The research work was funded by the Shiraz University and was approved by the Ethics Committee of Biology Department (ECBD-SU9233856). The genetic work was funded by Swiss Science Foundation grant 31003A_144046 to OS.

\section{References}

Abdoli, A., 2000. The Inland Water Fishes of Iran. Iranian Museum of Nature and Wildlife, Tehran.

Afshar, S. I., 2000. Shenakht-e Ostan-e Hormozgan. Hyrmand press, Tehran.

Banister, K. E \& M. A. Clarke, 1977. The freshwater fishes of the Arabian Peninsula. The Scientific Results of the Oman Flora and Fauna Survey 1975 The Journal of Oman Studies Special Report No, 1.

Both, B., 1977. The making of Iran. Geographyc Magazine 1977: 243-249.

Brawand, D., C. E. Wagner, Y. I. Li, M. Malinsky, I. Keller, S. Fan, et al., 2014. The genomic substrate for adaptive radiation in African cichlid fish. Nature 513: 375-381.

Clement, M., D. Posada \& K. Crandall, 2000. TCS: a computer program to estimate gene genealogies. Molecular Ecology 9: 1657-1660.

Coad, B. W., 1982. A new genus and species of cichlid endemic to southern Iran. Copeia 1: 28-37.

Dijkstra, P. D., J. Lindström, N. B. Metcalfe, C. K. Hemelrijk, M. Brendel, O. Seehausen \& T. G. G. Groothuis, 2010. Frequency-dependent social dominance in a color polymorphic cichlid fish. Evolution 64: 2797-2807.

Dupanloup, I., S. Schneider, \& L. Excoffier, 2002. A simulated annealing approach to define the genetic structure of populations. Molecular Ecology 11: 2571-2581.

Edgar, R. C., 2004. MUSCLE: a multiple sequence alignment method with reduced time and space complexity. BMC Bioinformatics 5: 113.
Esmaeili, H. R., 2014. Ein ungewöhnlicher Endemit aus dem Iran. DATZ 05: 32-36.

Esmaeili, H. R., Z. Ganjali \& M. Monsefi, 2008. Reproductive biology of the endemic Iranian cichlid, Iranocichla hormuzensis Coad, 1982 from Mehran River, southern Iran. Environmental Biology of Fishes 84: 141-145.

Esmaeili, H. R., B. W. Coad, A. Gholamifard, N. Nazari \& A. Teimory, 2010. Annotated checklist of the freshwater fishes of Iran. Zoosystematica Rossica 19: 361-386.

Esmaeili, H. R., A. Khajepana, H. Mehraban, E. L. M. I. Amir, H. Melekzehi \& A. Pazira, 2015. Fishes of the Mashkid and Makran basins of Iran: an updated checklist and ichthyogeography. Iranian Journal of Ichthyology 2: 113-132.

Excoffier, L. \& H. E. Lischer, 2010. Arlequin suite ver 3.5: a new series of programs to perform population genetics analyses under Linux and Windows. Molecular Ecology Resources 10: 564-567.

Freyhof, J. F. G., Ekmekçi, A. Ali., Khamees, N. R., Özulu, M., Hamidan, N., Küçük, F \& K. G. Smith, 2014. Freshwater fishes (Chap. 3), In Smith, K. G., V. Barrios, W. R. T. Darwall \& C. Numa (eds), The Status and Distribution of Freshwater Biodiversity in the Eastern Mediterranean. 19-42.

Fryer, G. \& T. D. Iles, 1972. Cichlid Fishes of the Great Lakes of Africa. Oliver \& Boyd, Edinburgh.

Fu, Y. X., 1997. Statistical tests of neutrality of mutations against population growth, hitchhiking and background selection. Genetics 147: 915-925.

Genner, M. J., O. Seehausen, D. H. Lunt, D. A. Joyce, P. W. Shaw, G. R. Carvalho \& G. F. Turner, 2007. Age of cichlids: new dates for ancient lake fish radiations. Molecular Biology and Evolution 24: 1269-1282.

Harpending, H. C., 1994. Signature of ancient population growth in a low-resolution mitochondrial DNA mismatch distribution. Human Biology 66: 591-600.

Ho, S. Y., M. J. Phillips, A. Cooper \& A. J. Drummond, 2005. Time dependency of molecular rate estimates and systematic overestimation of recent divergence times. Molecular Biology and Evolution 22: 1561-1568.

Hojat Ansari, T., 2008. Food, feeding and age determination of Iranocichla hormuzensis Coad, 1982 (Perciformes: Cichlidae). M.Sc. thesis. Submitted to Biology Department, Shiraz University, Shiraz.

Jayaram, K. C., 1999. The Freshwater Fishes of the Indian Region. Narendra Publishing House, Delhi. 551 p.

Kearse, M., R. Moir, A. Wilson, S. Stones-Havas, M. Cheung, S. Sturrock, S. Buxton, A. Cooper, S. Markowitz, C. Duran, T. Thierer, B. Ashton, P. Mentjies \& A. Drummond, 2012. Geneious Basic: an integrated and extendable desktop software platform for the organization and analysis of sequence data. Bioinformatics 28: 1647-1649.

Kehl, M., 2009. Quaternary climate change in Iran — the state of knowledge. Erdkunde 63: 1-17.

Kocher, T. D., 2004. Adaptive evolution and explosive speciation: the cichlid fish model. Nature Reviews Genetics 5: 288-298.

Kocher, T. D., W. K. Thomas, A. Meyer, S. V. Edwards, S. Paabo, F. X. Villablance \& A. C. Wilson, 1989. Dynamics of mitochondrial DNA evolution in animals: amplification and sequencing with conserved primers. Proceedings of the National Academy of Sciences 86: 6196-6200. 
Kocher, T. D., J. A. Conroy, K. R. McKaye, J. R. Stauffer \& S. F. Lockwood, 1995. Evolution of NADH dehydrogenase subunit 2 in East African cichlid fish. Molecular Phylogenetics and Evolution 4: 420-432.

Kosswig, C., 1965. Zur historischen Zoogeographie der Ichthyofauna im Süsswasser des sudlichen Kleinasiens. Zoologische Jahrbücher für Systematik 92: 83-90.

Kosswig, C., 1973. Über die Ausbreitungswege sogenannter perimediterraner Süsswasserfische. Bonner Zoologische Beiträge 24: 165-177.

Kullander, S. O., 1998. A phylogeny and classification of the South American Cichlidae (Teleostei: Perciformes). Phylogeny and classification of Neotropical fishes 31 : 461-498.

Kumar, S., K. Tamura \& M. Nei, 2004. MEGA3: integrated software for molecular evolutionary genetics analysis and sequence alignment. Briefings in Bioinformatics 5: 150-163.

Lambeck, K., 1988. Geophysical Geodesy. Clarendon, Oxford: 718.

Lambeck, K., 1996. Shoreline reconstructions for the Persian Gulf since the last glacial maximum. Earth and Planetary Science Letters 142: 43-57.

Nelson, J. S., 2006. Fishes of the World. Wiley, New York.

Purser, B. H. \& E. Seibold, 1973. The principal environmental factors influencing Holocene sedimentation and diagenesis in the Persian Gulf. In Purser, B. H. (ed.), the Persian Gulf. Springer, Berlin: 1-19.

Regard, V., O. Bellier, J. C. Thomas, M. Abbassi, J. L. Mercier, E. Shabanian, K. H. Feghhi \& S. H. Soleymaani, 2004. The accommodation of the Arabia-Asia convergence in the Zagros-Makran transfer zone, SE Iran: a transition between collision and subduction through a young deforming system. Tectonics 23: 1-24.

Sarnthein, M., 1972. Sediments and history of the postglacial transgression in the Persian Gulf and northwest Gulf of Oman. Marine Geology 12: 245-266.

Schneider, S. \& L. Excoffier, 1999. Estimation of demographic parameters from the distribution of pairwise differences when the mutation rates vary among sites: application to human mitochondrial DNA. Genetics 152: 1079-1089.

Schwarzer, J., B. Misof, D. Tautz \& U. K. Schliewen, 2009. The root of the East African cichlid radiations. BMC Evolutionary Biology 9: 186.

Schulz, T., 2004. Iran, der dritte Versuch. Die Aquarien- und Terrarienzeitschrift 57: 24-27.
Seehausen, O., 2006. African cichlid fish: a model system in adaptive radiation research. Proceedings of the Royal Society of London B 273: 1987-1998.

Seehausen, O., 2015. Process and pattern in cichlid radiationsinferences for understanding unusually high rates of evolutionary diversification. New Phytologist 207: 304-312.

Seehausen, O. \& D. Schluter, 2004. Male-male competition and nuptial-colour displacement as a diversifying force in Lake Victoria cichlid fishes. Proceedings of the Royal Society of London B 271: 1345-1353.

Selz, O. M., M. E. Pierotti, M. E. Maan, C. Schmid \& O. Seehausen, 2014a. Female preference for male color is necessary and sufficient for assortative mating in 2 cichlid sister species. Behavioral Ecology 25: 612-626.

Selz, O. M., R. Thommen, M. E. Maan \& O. Seehausen, 2014b. Behavioural isolation may facilitate homoploid hybrid speciation in cichlid fish. Journal of Evolutionary Biology 27: 275-289.

Stamatakis, A., 2006. RAxML-VI-HPC: maximum likelihoodbased phylogenetic analyses with thousands of taxa and mixed models. Bioinformatics 22: 2688-2690.

Stiassny, M. L. J., G. De Marchi \& A. Lamboj, 2010. A new species of Danakilia (Teleostei, Cichlidae) from Lake Abaeded in the Danakil Depression of Eritrea (East Africa). Zootaxa 2690: 43-52.

Tajima, F., 1989. Statistical method for testing the neutral mutation hypothesis by DNA polymorphism. Genetics 123: 585-595.

Teimori, A., 2013. The Evolutionary History and Taxonomy of Aphanius (Teleostei: Cyprinodontidae) Species in Iran and the Persian Gulf Region (Doctoral dissertation, München, Ludwig-Maximilians-Universität, Diss., 2013).

Teller, J. T., K. W. Glennie, N. Lancaster \& A. K. Singhvi, 2000. Calcareous dunes of the United Arab Emirates and Noah's Flood: the postglacial reflooding of the Persian (Arabian) Gulf. Quaternary International 68: 297-308.

Trewavas, E., 1983. Tilapiine Fishes of the Genera Sarotherodon, Oreochromis and Danakilia. British Museum of Natural History, London.

Verheyen, E., W. Salzburger, J. Snoeks \& A. Meyer, 2003. Origin of the superflock of cichlid fishes from Lake Victoria, East Africa. Science 300: 325-329.

Wagner, C. E., L. J. Harmon \& O. Seehausen, 2012. Ecological opportunity and sexual selection together predict adaptive radiation. Nature 487: 366-369. 